Article

\title{
Investigation into the Effect of Sulfate and Borate Incorporation on the Structure and Properties of $\mathrm{SrFeO}_{3-\delta}$
}

\author{
Abbey Jarvis and Peter Raymond Slater * \\ School of Chemistry, University of Birmingham, Birmingham B15 2TT, UK; axj278@student.bham.ac.uk \\ * Correspondence: p.r.slater@bham.ac.uk; Tel.: +44-121-414-8906
}

Academic Editor: Stevin Pramana

Received: 28 April 2017; Accepted: 3 June 2017; Published: 7 June 2017

\begin{abstract}
In this paper, we demonstrate the successful incorporation of sulfate and borate into $\mathrm{SrFeO}_{3-\delta}$, and characterise the effect on the structure and conductivity, with a view to possible utilisation as a cathode material in Solid Oxide Fuel Cells. The incorporation of low levels of sulfate/borate is sufficient to cause a change from a tetragonal to a cubic cell. Moreover, whereas heat treatment of undoped $\mathrm{SrFeO}_{3-\delta}$ under $\mathrm{N}_{2}$ leads to a transformation to brownmillerite $\mathrm{Sr}_{2} \mathrm{Fe}_{2} \mathrm{O}_{5}$ with oxygen vacancy ordering, the sulfate/borate-doped samples remain cubic under the same conditions. Thus, sulfate/borate doping appears to be successful in introducing oxide ion vacancy disorder in this system.
\end{abstract}

Keywords: solid oxide fuel cell; cathode; perovskite; sulfate; borate

\section{Introduction}

Research into solid oxide fuel cells (SOFCs) as alternate energy materials has grown due to their high efficiency and consequent reduction in greenhouse gas emissions. Specifically, research into perovskite materials has attracted significant interest for potential SOFC materials including cathode, electrolyte and anode materials (see, for example, the review articles [1,2]). Traditionally, doping strategies for perovskite materials has involved the introduction of cations of a similar size e.g., $\mathrm{Sr}^{2+}$ for $\mathrm{La}^{3+}, \mathrm{Mg}^{2+}$ for $\mathrm{Ga}^{3+}$ to give the oxide ion conducting electrolyte $\mathrm{La}_{1-x} \mathrm{Sr}_{\mathrm{x}} \mathrm{Ga}_{1-y} \mathrm{Mg}_{y} \mathrm{O}_{3-\mathrm{x} / 2-\mathrm{y} / 2}$ [3] . More recently, we have applied oxyanion (silicate, phosphate, sulfate, borate) doping strategies to improve the properties of solid oxide fuel cell materials, initially demonstrating the successful incorporation into $\mathrm{Ba}_{2} \mathrm{In}_{2} \mathrm{O}_{5}$ [4]. Research on oxyanion incorporation into perovskites was initially reported for superconducting cuprate materials. This work showed that a wide range of oxyanions (carbonate, borate, nitrate, sulfate, and phosphate) could be incorporated into the perovskite structure [5-12]. In this doping strategy, the central ion of the oxyanion group is located on the perovskite B cation site, with the oxygens of this group occupying either three (borate, carbonate, nitrate) or four (sulfate, phosphate) of the available six anion positions around this site, albeit suitably displaced to achieve the correct coordination for the oxyanion group. As an extension to this work on cuprate superconductors, we have demonstrated successful oxyanion doping of perovskite materials for SOFC applications. This has included oxyanion (sulfate, silicate, phosphate) doping of $\mathrm{Ba}_{2}(\mathrm{In} / \mathrm{Sc})_{2} \mathrm{O}_{5}$ electrolyte materials [13-16]. Doping with these oxyanions introduces disorder on the oxygen sublattice, leading to improvements in the ionic conductivity. This work has also been extended to potential solid oxide fuel cell electrode materials, with successful oxyanion doping in the perovskite systems $\mathrm{SrCoO}_{3}$ [17-20], $\mathrm{SrCo}_{0.85} \mathrm{Fe}_{0.15} \mathrm{O}_{3}$ [21], $\mathrm{SrMnO}_{3}$ [18], $\mathrm{CaMnO}_{3}$ [22] and $\mathrm{SrFeO}_{3-\delta}$ [23], with the results suggesting improved performance/stability. 
Following the prior work demonstrating the successful incorporation of silicate into $\mathrm{SrFeO}_{3-\delta}$ [23], we report in this paper an investigation into the effect of sulfate and borate doping. The undoped system $\mathrm{SrFeO}_{3-\delta}$ has attracted interest due to its high ionic and electronic conductivity, however under low $\mathrm{p}\left(\mathrm{O}_{2}\right)$ the oxide ion (and electronic conductivity) are significantly reduced. This is due to oxygen loss leading to a transformation to the oxygen vacancy ordered brownmillerite structure, $\mathrm{Sr}_{2} \mathrm{Fe}_{2} \mathrm{O}_{5}$ (Figure 1). We have therefore investigated the effect of borate/sulfate doping on this transformation.

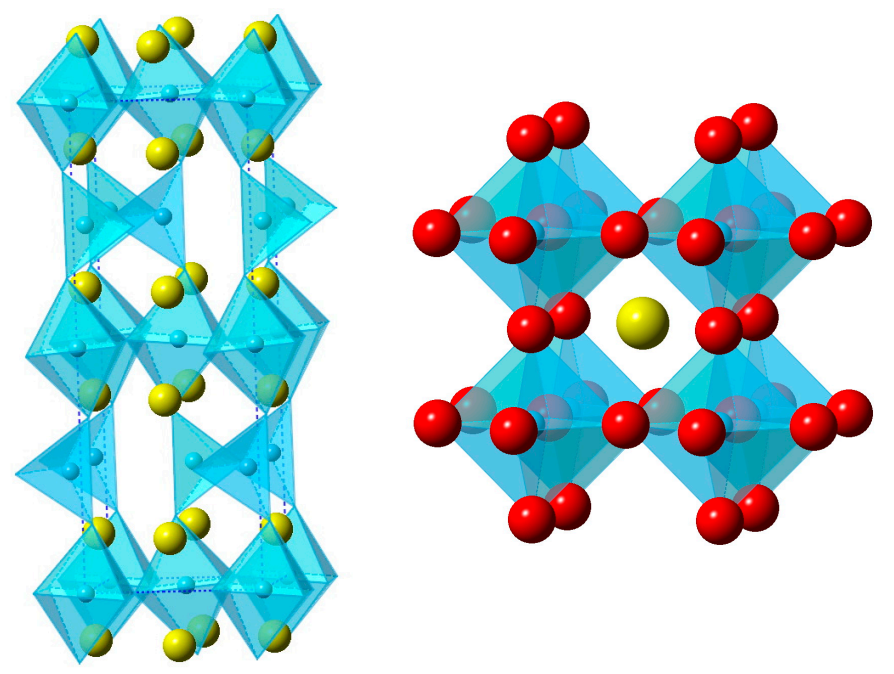

Figure 1. Structure of $\mathrm{Sr}_{2} \mathrm{Fe}_{2} \mathrm{O}_{5}$ (showing oxygen vacancy ordering) (left) and $\mathrm{SrFeO}_{3}$ (right).

\section{Results and Discussion}

\section{1. $\mathrm{SrFe}_{1-x} \mathrm{~S}_{x} \mathrm{O}_{3-\delta}$}

\subsubsection{X-ray Diffraction Data}

A range of samples of $\mathrm{SrFe}_{1-x} \mathrm{~S}_{\mathrm{x}} \mathrm{O}_{3-\delta}$ with increasing sulfate content $(0 \leq \mathrm{x} \leq 0.1)$ were prepared. X-ray diffraction analysis showed that without sulfate doping $\mathrm{SrFeO}_{3-\delta}$ forms a tetragonal perovskite in line with prior reports. This is illustrated in Figure 2 (expanded region $2 \theta=45^{\circ}$ to $60^{\circ}$ ) where peak splitting can clearly be observed. Upon doping with sulfate, there is a transformation to a cubic cell $(0.025 \leq \mathrm{x} \leq 0.075)$, where no peak splitting is now observed (Figure 2). Above $\mathrm{x}=0.075$, small $\mathrm{SrSO}_{4}$ impurities appear, suggesting that the solubility limit of sulfate in $\mathrm{SrFe}_{1-x} \mathrm{~S}_{\mathrm{x}} \mathrm{O}_{3-\delta}$ is $\mathrm{x} \approx 0.075$.
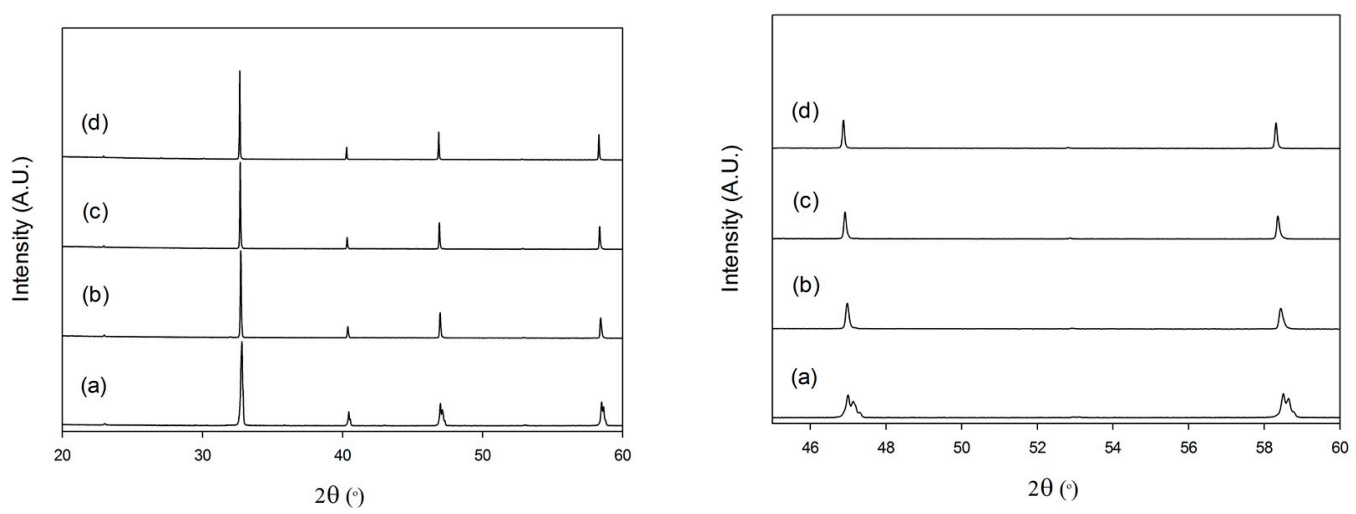

Figure 2. Cont. 


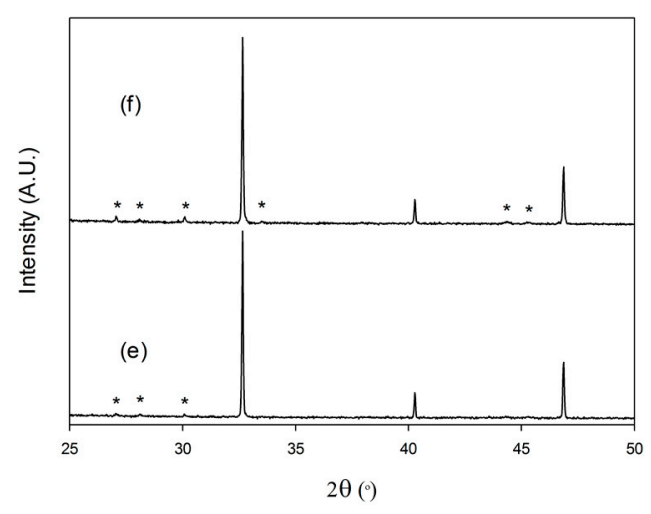

Figure 2. X-ray diffraction patterns for (a) $\mathrm{SrFeO}_{3-\delta}$, (b) $\mathrm{SrFe}_{0.975} \mathrm{~S}_{0.025} \mathrm{O}_{3-\delta}$, (c) $\mathrm{SrFe}_{0.95} \mathrm{~S}_{0.05} \mathrm{O}_{3-\delta}$, (d) $\mathrm{SrFe}_{0.925} \mathrm{~S}_{0.075} \mathrm{O}_{3-\delta}$, (e) $\mathrm{SrFe}_{0.9} \mathrm{~S}_{0.1} \mathrm{O}_{3-\delta}$, and (f) $\mathrm{SrFe}_{0.85} \mathrm{~S}_{0.15} \mathrm{O}_{3-\delta}$. The data show a tetragonal cell for $\mathrm{SrFeO}_{3-\delta}$, (as highlighted by the peak splitting: see expanded region Figure $2 \theta=45^{\circ}$ to $60^{\circ}$ ), while the sulfate-doped samples are cubic. $\mathrm{SrSO}_{4}$ impurities (highlighted by an asterisk) are observed for samples with higher sulfate contents $(x=0.1$ and 0.15$)$.

In order to provide further support for the incorporation of sulfate, equivalent Fe-deficient samples were prepared without addition of sulfate. The X-ray diffraction data for $\mathrm{SrFe}_{0.95} \mathrm{O}_{3-\delta}$ (Fe-deficient, no sulfate) and $\mathrm{SrFe}_{0.95} \mathrm{~S}_{0.05} \mathrm{O}_{3-\delta}$ are compared in Figure 3. These data show the presence of impurities for $\mathrm{SrFe}_{0.95} \mathrm{O}_{3-\delta}$ along with peak splitting, consistent with a tetragonal cell, as for the undoped $\mathrm{SrFeO}_{3-\delta}$ parent phase. In contrast, impurities are not observed for the sulfate-containing phase $\mathrm{SrFe}_{0.95} \mathrm{~S}_{0.05} \mathrm{O}_{3-\delta}$, and the cell is now cubic. Therefore, this comparison provides further evidence for the successful incorporation of sulfate.
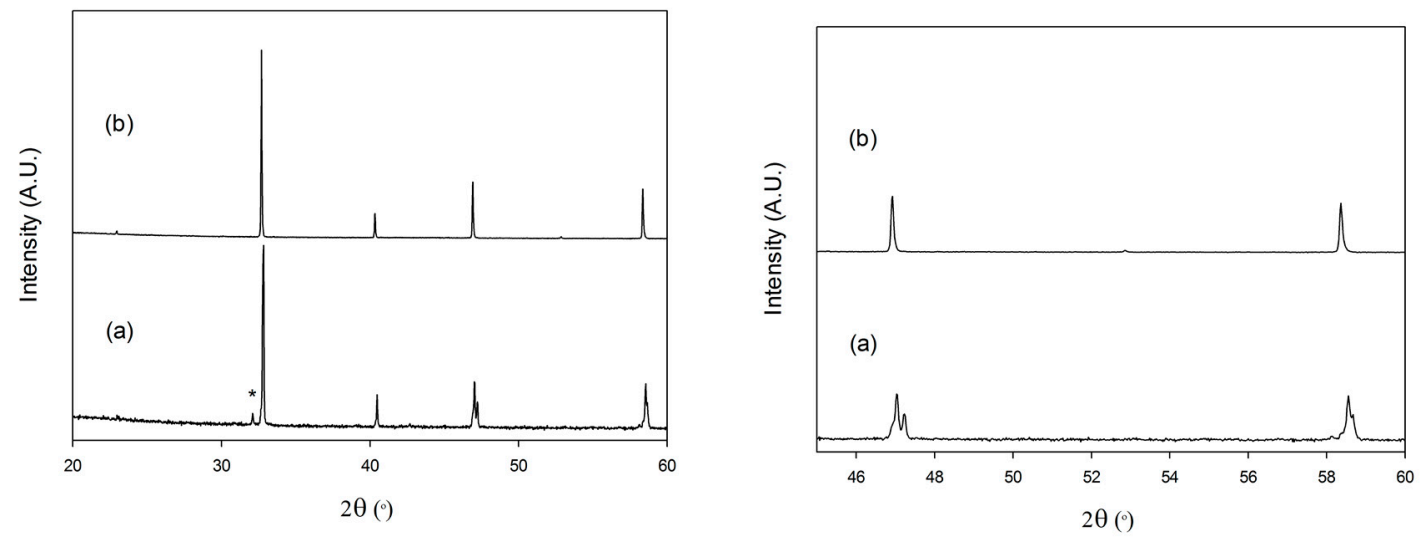

Figure 3. X-ray diffraction patterns for (a) $\mathrm{SrFe}_{0.95} \mathrm{O}_{3-\delta}$ (Fe-deficient, no sulfate) and (b) $\mathrm{SrFe}_{0.95} \mathrm{~S}_{0.05} \mathrm{O}_{3-\delta}$. The data show impurities (highlighted by an asterisk) and a tetragonal cell for $\mathrm{SrFe}_{0.95} \mathrm{O}_{3-\delta}$, while the sulfate-containing sample $\mathrm{SrFe}_{0.95} \mathrm{~S}_{0.05} \mathrm{O}_{3-\delta}$ is phase pure and cubic.

Cell parameters for all these phases were determined using the Rietveld method (an example fit is shown in Figure 4). The variation of the cell parameters for $\mathrm{SrFe}_{1-x} \mathrm{~S}_{\mathrm{x}} \mathrm{O}_{3-\delta}$ with increasing sulfate content is given in Table 1. The data show a small general increase with increasing sulfate content, and this will be discussed in more detail in Section 2.1.4. 


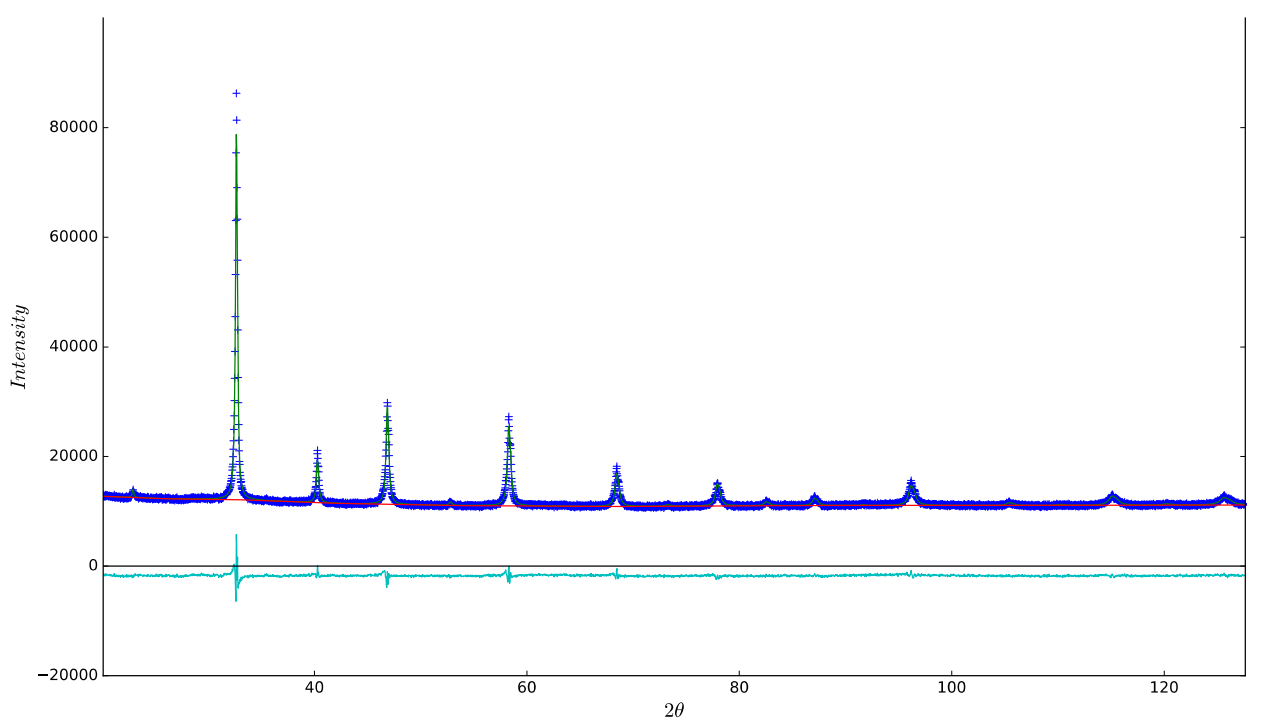

Figure 4. Observed, calculated and difference $\mathrm{X}$-ray diffraction profile for $\mathrm{SrFe}_{0.975} \mathrm{~S}_{0.025} \mathrm{O}_{3-\delta}$.

In addition to the determination of the unit cell parameters, site occupancies were refined for the $\mathrm{Fe} / \mathrm{S}$ site. These occupancies are given in Table 1, and show that the refined values are in good agreement with the expected values.

Table 1. Lattice parameters and $\mathrm{Fe} / \mathrm{S}$ site occupancies obtained from Rietveld refinement using XRD data for $\mathrm{SrFe}_{1-x} \mathrm{~S}_{\mathrm{x}} \mathrm{O}_{3-\delta}$. The structure of $\mathrm{SrFeO}_{3-\delta}$ was refined using a tetragonal space group $(\mathrm{P} 4 / \mathrm{mmm})$. The structures of the sulfate-doped samples were refined using a cubic space group (Pm3̄m).

\begin{tabular}{ccccc}
\hline \multicolumn{5}{c}{$\mathrm{SrFe}_{1-\mathrm{x}} \mathrm{S}_{\mathbf{x}} \mathrm{O}_{3-\delta}$} \\
$\mathrm{S}(\mathrm{x})$ & 0 & 0.025 & 0.05 & 0.075 \\
$\mathrm{a}(\AA)$ & $3.8648(1)$ & $3.8723(1)$ & $3.8776(1)$ & $3.8766(1)$ \\
$\mathrm{c}(\AA)$ & $3.8487(1)$ & - & - & - \\
$\mathrm{V}\left(\AA^{3}\right)$ & $57.486(4)$ & $58.066(2)$ & $58.303(4)$ & $58.260(4)$ \\
$\mathrm{R}_{\mathrm{wp}}(\%)$ & 1.84 & 1.67 & 2.01 & 1.97 \\
$\mathrm{R}_{\text {exp }}(\%)$ & 0.92 & 0.92 & 0.90 & 0.90 \\
$\mathrm{Fe}$ occupancy & 1 & $0.98(1)$ & $0.96(1)$ & $0.94(1)$ \\
$\mathrm{S}$ occupancy & - & $0.02(1)$ & $0.04(1)$ & $0.06(1)$ \\
Fe/S Uiso & $0.003(1)$ & $0.009(1)$ & $0.011(1)$ & $0.008(1)$ \\
\hline
\end{tabular}

\subsubsection{Stability under $\mathrm{N}_{2}$}

The effect of heating the $\mathrm{SrFe}_{1-x} \mathrm{~S}_{\mathrm{x}} \mathrm{O}_{3-\delta}$ samples under $\mathrm{N}_{2}$ was then examined. Upon heating under $\mathrm{N}_{2}$ to $950{ }^{\circ} \mathrm{C}$, the X-ray diffraction data showed that $\mathrm{SrFeO}_{3-\delta}$ transforms to the oxygen vacancy ordered brownmillerite type $\mathrm{Sr}_{2} \mathrm{Fe}_{2} \mathrm{O}_{5}$ (Figures 1 and 5). This would be expected to be unfavorable for fuel cell applications due to the ordering of oxygen vacancies, which is expected to lower the oxide ion conductivity. In contrast, for the sulfate-doped samples, the disordered cubic perovskite is retained under a similar heat treatment. For the $x=0.025$ sample, there are some very weak peaks (see expanded XRD figure) associated with the brownmillerite structure, but for the higher sulfate contents $(x \geq 0.05)$, a single phase cubic cell is observed. In line with the reduction in the Fe oxidation state towards $3+$, there is an increase in the cell parameters associated with the larger size of $\mathrm{Fe}^{3+}$ versus $\mathrm{Fe}^{4+}$ (Table 2). 

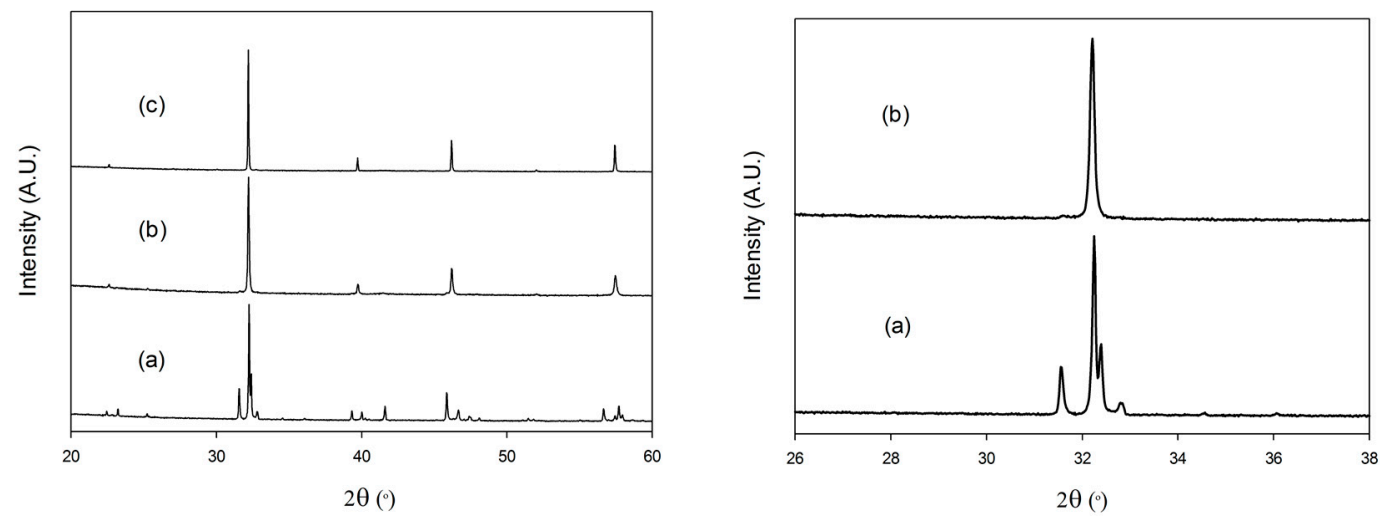

Figure 5. X-ray diffraction patterns of (a) $\mathrm{SrFeO}_{3-\delta}$, (b) $\mathrm{SrFe}_{0.975} \mathrm{~S}_{0.025} \mathrm{O}_{3-\delta}$, and (c) $\mathrm{SrFe}_{0.95} \mathrm{~S}_{0.05} \mathrm{O}_{3-\delta}$ after heating under $\mathrm{N}_{2}$ to $950^{\circ} \mathrm{C}$.

Table 2. Lattice parameters for $\mathrm{SrFe}_{1-x} \mathrm{~S}_{\mathrm{x}} \mathrm{O}_{3-\delta}$ after heating in air and $\mathrm{N}_{2}$.

\begin{tabular}{ccccccc}
\hline \multicolumn{8}{c}{$\mathrm{SrFe}_{1-\mathbf{x}} \mathrm{S}_{\mathbf{x}} \mathbf{O}_{3-\delta}$} \\
$\mathrm{S}(\mathrm{x})$ & Air & 0.025 & \multicolumn{2}{c}{0.05} & \multicolumn{2}{c}{0.075} \\
$\mathrm{a}(\AA)$ & $3.8723(1)$ & $3.9231(1)$ & $3.8776(1)$ & $3.9256(1)$ & $3.8766(1)$ & $3.9280(1)$ \\
$\mathrm{c}(\AA)$ & - & - & - & - & - & - \\
$\mathrm{V}\left(\AA^{3}\right)$ & $58.066(2)$ & $60.379(1)$ & $58.303(4)$ & $60.496(1)$ & $58.260(4)$ & $60.606(1)$ \\
$\mathrm{R}_{\mathrm{wp}}(\%)$ & 1.67 & 3.10 & 2.01 & 3.09 & 1.97 & 3.20 \\
$\mathrm{R}_{\exp }(\%)$ & 0.92 & 2.59 & 0.90 & 2.51 & 0.90 & 2.50 \\
\hline
\end{tabular}

\subsubsection{Thermogravimetric Analysis}

Thermogravimetric analysis (TGA) (heat treatment in $\mathrm{N}_{2}$ to reduce the Fe oxidation state to $3+$ ) was then utilized to determine the oxygen contents of the samples as prepared in air. This analysis resulted in an interesting observation associated with Mass spectrometry analysis of the evolved gas. For the undoped sample $\mathrm{SrFeO}_{3-\delta}$, the loss of mass is only associated with oxygen as indicated by the mass spectrometry data. However, for the sulfate-doped samples, a mass loss associated with $\mathrm{CO}_{2}$ was observed in addition to the expected mass loss due to $\mathrm{O}_{2}$.

Thus, the results indicated the presence of some carbonate in the sulfate-doped samples. In order to remove this carbonate, heat treatment in $\mathrm{O}_{2}$ (up to $900{ }^{\circ} \mathrm{C}$ ) was carried out for these $\mathrm{SrFe}_{1-x} \mathrm{~S}_{\mathrm{x}} \mathrm{O}_{3-\delta}$ samples. After this oxygen treatment, TGA analysis indicated no presence of carbonate. This is illustrated in Figure 6, where a mass loss associated with $\mathrm{CO}_{2}$ is not observed after heat treatment in $\mathrm{O}_{2}$ for $\mathrm{SrFe}_{0.95} \mathrm{~S}_{0.05} \mathrm{O}_{3-\delta}$. 


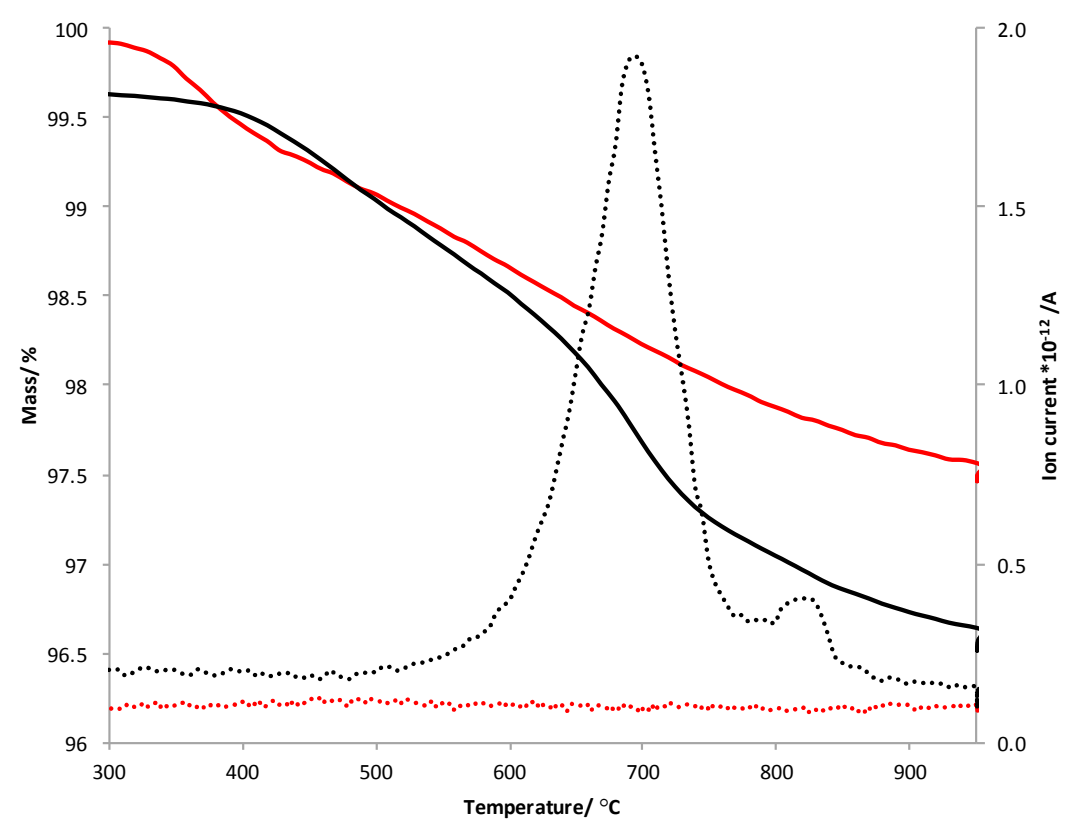

Figure 6. Plot of mass vs. temperature and ion current (for $m / z=44 ; \mathrm{CO}_{2}$ ) vs. temperature (under $\mathrm{N}_{2}$ ) for $\mathrm{SrFe}_{0.95} \mathrm{~S}_{0.05} \mathrm{O}_{3-\delta}$ prepared in air (black) and $\mathrm{O}_{2}$ (red), showing a mass loss associated with $\mathrm{CO}_{2}$ in the air synthesised sample, which is eliminated after heat treatment in $\mathrm{O}_{2}$. Solid lines indicate \%mass and dashed lines indicate ion current.

The TGA results indicating the presence of carbonate may at first glance suggest the existence of a small amount of $\mathrm{SrCO}_{3}$ impurity. However, the temperature at which the $\mathrm{CO}_{2}$ is lost is significantly lower than would be expected for $\mathrm{SrCO}_{3}$. In order to illustrate this, TGA data for $\mathrm{SrCO}_{3}$ were also collected and compared to the data for the $\mathrm{SrFe}_{0.95} \mathrm{~S}_{0.05} \mathrm{O}_{3-\delta}$. This experiment shows a significant difference in the temperature at which the loss of $\mathrm{CO}_{2}$ occurs for $\mathrm{SrFe}_{0.95} \mathrm{~S}_{0.05} \mathrm{O}_{3-\delta}$ and $\mathrm{SrCO}_{3}$. In particular, the starting temperature for $\mathrm{CO}_{2}$ loss for $\mathrm{SrFe}_{0.95} \mathrm{~S}_{0.05} \mathrm{O}_{3-\delta}$ occurs at a significantly lower temperature $\left(\approx 490{ }^{\circ} \mathrm{C}\right.$ vs. $\approx 760{ }^{\circ} \mathrm{C}$ for $\left.\mathrm{SrCO}_{3}\right)$, which may suggest that this carbonate is present in the perovskite structure, i.e., we have a mixed sulfate/carbonate-doped sample- $\mathrm{SrFe}_{1-x-y} \mathrm{~S}_{\mathrm{x}} \mathrm{C}_{\mathrm{y}} \mathrm{O}_{3-\delta}$. Further work is required to investigate this possibility, although as noted in the introduction, carbonate has been shown previously to be accommodated in perovskite materials.

Given the dual $\left(\mathrm{O}_{2}\right.$ and $\left.\mathrm{CO}_{2}\right)$ mass loss for the air-synthesized $\mathrm{SrFe}_{1-\mathrm{x}} \mathrm{S}_{\mathrm{x}} \mathrm{O}_{3-\delta}$ samples, it is not possible to determine reliable oxygen contents for these samples. In addition, as detailed by Starkov et al., the determination of oxygen contents in partially substituted ferrites is non-trivial without a reliable fixed reference point [24]. Since it is possible that there may still be a small amount of $\mathrm{Fe}^{4+}$ in these samples after the $\mathrm{N}_{2}$ treatment, there is not a conclusive fixed reference oxygen point, and so any calculated oxygen contents would only be rough approximations.

\subsubsection{Heat Treatment under $\mathrm{O}_{2}$}

The samples (described above) heated under $\mathrm{O}_{2}$ were also examined by $\mathrm{X}$-ray diffraction (Figure 7). All the sulfate-doped $\mathrm{SrFe}_{1-x} \mathrm{~S}_{\mathrm{x}} \mathrm{O}_{3-\delta}$ samples were shown to retain their original cubic structure while undoped $\mathrm{SrFeO}_{3-\delta}$ remained tetragonal. 


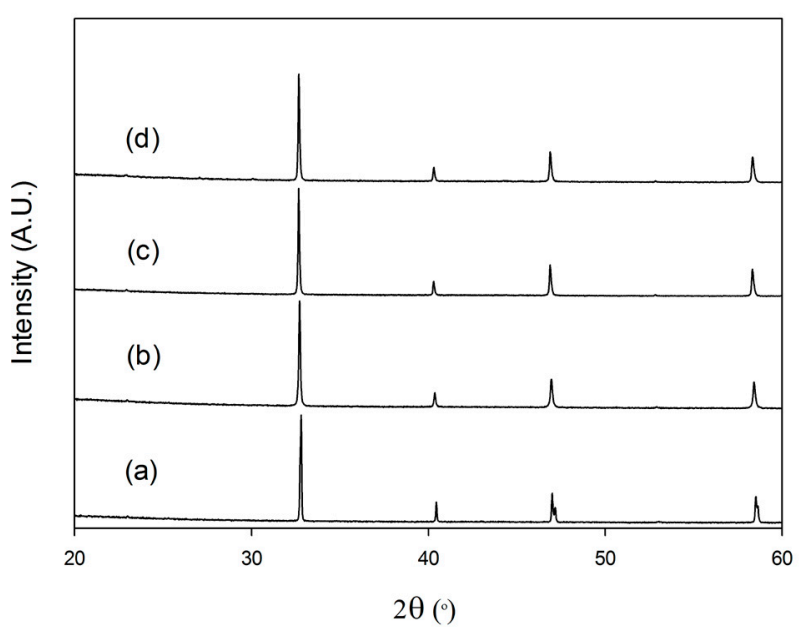

Figure 7. X-ray diffraction patterns of (a) $\mathrm{SrFeO}_{3-\delta}$, (b) $\mathrm{SrFe}_{0.975} \mathrm{~S}_{0.025} \mathrm{O}_{3-\delta}$, (c) $\mathrm{SrFe}_{0.95} \mathrm{~S}_{0.05} \mathrm{O}_{3-\delta}$, and (d) $\mathrm{SrFe}_{0.925} \mathrm{~S}_{0.075} \mathrm{O}_{3-\delta}$ after heating under $\mathrm{O}_{2}$.

Cell parameters and site occupancies were determined by Rietveld refinement using the X-ray diffraction data. From these structure refinements (Table 3), there is a decrease in the unit cell parameters upon heating in $\mathrm{O}_{2}$. This can be more clearly seen in Figure 8 where the variation in cell volume versus sulfate content is compared for samples heated in $\mathrm{O}_{2}$ and those just heated in air. These data show a reduction in cell volume on heating in oxygen, which can be correlated with a greater concentration of the smaller $\mathrm{Fe}^{4+}$ as a result of an increase in oxygen content. The cell parameter data also show an interesting variation with sulfate content, with an approximately linear increase in cell volume up to $x=0.05$. The fact that there is no further increase for $x=0.075$ may therefore suggest that the sulfate solubility limit is closer to $x=0.05$.

The increase in cell volume with increasing sulfate content is at first glance unexpected given that $\mathrm{S}^{6+}$ is significantly smaller than $\mathrm{Fe}^{3+/ 4+}$. One possible explanation could relate to changes in the $\mathrm{Fe}^{3+} / \mathrm{Fe}^{4+}$ ratio on sulfate incorporation. However, this cell volume increase is also seen for the $\mathrm{N}_{2}$ treated samples (Table 2), where we only have $\mathrm{Fe}^{3+}$, and thus another factor must be significant. In this respect, the cell volume increase may be associated with the extra oxygen associated with this dopant. Thus, if we take the case of the $\mathrm{N}_{2}$ treated samples, we are effectively replacing $\mathrm{Fe}(\mathrm{III}) \mathrm{O}_{1.5}$ with $\mathrm{SO}_{3}$, which means the introduction of an extra 1.5 oxide ions per sulfate, which might be expected to contribute to an expanded cell size.

Table 3. Lattice parameters and Fe/S site occupancies for $\mathrm{SrFe}_{1-x} \mathrm{~S}_{x} \mathrm{O}_{3-\delta}$, obtained from Rietveld refinement using XRD data for $\mathrm{SrFe}_{1-\mathrm{x}} \mathrm{S}_{\mathrm{x}} \mathrm{O}_{3-\delta}$ after heating in $\mathrm{O}_{2}$.

\begin{tabular}{ccccc}
\hline \multicolumn{5}{c}{$\mathbf{S r F e}_{\mathbf{1}-\mathbf{x}} \mathbf{S}_{\mathbf{x}} \mathbf{O}_{\mathbf{3}-\boldsymbol{\delta}}$ Heated in $\mathbf{O}_{\mathbf{2}}$} \\
\hline $\mathrm{S}(\mathrm{x})$ & 0 & 0.025 & 0.05 & 0.075 \\
$\mathrm{a}(\AA)$ & $3.8651(1)$ & $3.8641(1)$ & $3.8692(1)$ & $3.8691(1)$ \\
$\mathrm{c}(\AA)$ & $3.8477(1)$ & - & - & - \\
$\mathrm{V}\left(\AA^{3}\right)$ & $57.349(3)$ & $57.694(2)$ & $57.924(2)$ & $57.922(3)$ \\
$\mathrm{R}_{\mathrm{wp}}(\%)$ & 4.16 & 3.29 & 3.79 & 3.93 \\
$\mathrm{R}_{\exp }(\%)$ & 3.71 & 2.81 & 2.73 & 2.79 \\
$\mathrm{Fe} \mathrm{occ}$ & $1(-)$ & $0.97(2)$ & $0.94(2)$ & $0.93(2)$ \\
$\mathrm{S}$ occ & - & $0.03(2)$ & $0.06(2)$ & $0.07(2)$ \\
\hline
\end{tabular}




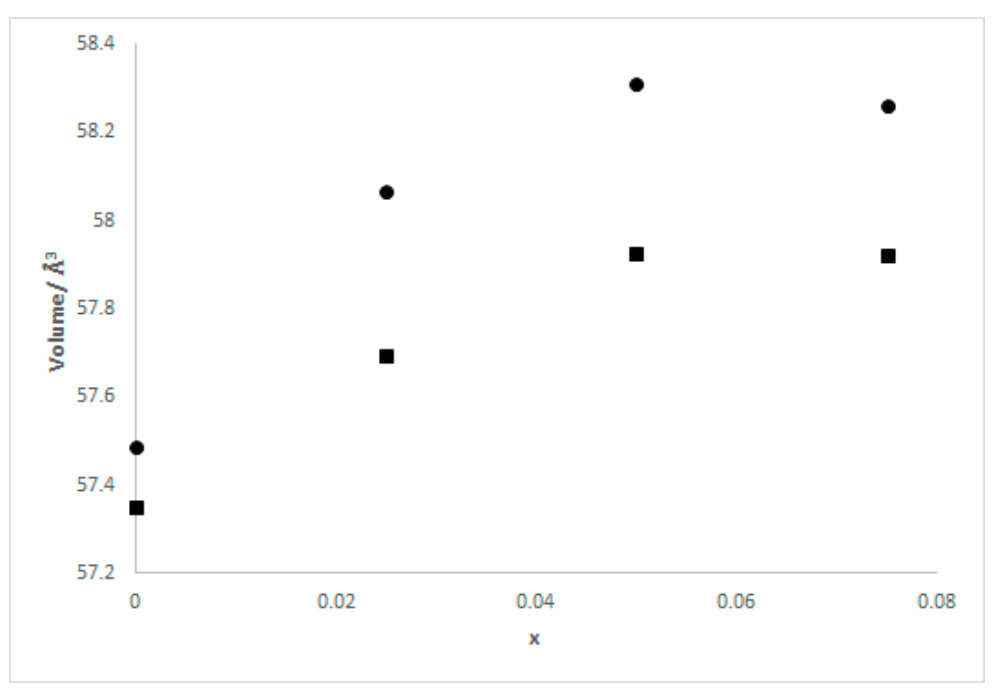

Figure 8. Plot of unit cell volume vs. $x$ for $\mathrm{SrFe}_{1-\mathrm{x}} \mathrm{S}_{\mathrm{x}} \mathrm{O}_{3-\delta}$ heated in air $(\bullet)$ and heated in $\mathrm{O}_{2}(\boldsymbol{\square})$.

\subsubsection{Conductivity Data}

Following the successful incorporation of sulfate, the conductivities of the $\mathrm{SrFe}_{1-x} \mathrm{~S}_{x} \mathrm{O}_{3-\delta}$ samples were examined in air. In general, the $\mathrm{SrFe}_{1-x} \mathrm{~S}_{\mathrm{x}} \mathrm{O}_{3-\delta}$ samples were found to have similar conductivities, with the exception of a notable decrease at lower temperatures for the higher sulfate content $(x=0.075)$ sample (Figure 9). This observation of a decrease in conductivity for higher dopant levels is comparable to the silicon-doped $\mathrm{SrFeO}_{3-\delta}$ system where it was proposed that at higher doping levels the silicate disrupts the Fe-O network resulting in a decrease in conductivity. [23]. Another factor, however, could relate to low levels of insulating impurities in this high sulfate content sample, given that the cell parameter data suggest that the sulfate solubility limit may be closer to $\mathrm{x}=0.05$.

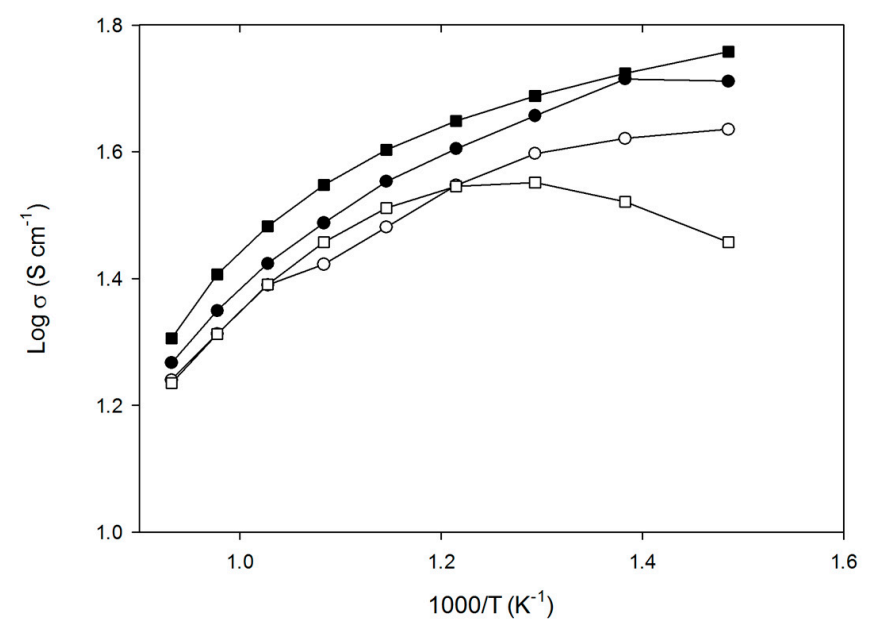

Figure 9. Plot of $\log \sigma$ vs. $1000 / \mathrm{T}$ for $\mathrm{SrFeO}_{3-\delta}(\bullet), \mathrm{SrFe}_{0.975} \mathrm{~S}_{0.025} \mathrm{O}_{3-\delta}(\bigcirc), \mathrm{SrFe}_{0.95} \mathrm{~S}_{0.05} \mathrm{O}_{3-\delta}(\mathbb{\square})$ and $\mathrm{SrFe}_{0.925} \mathrm{~S}_{0.075} \mathrm{O}_{3-\delta}(\square)$ in air.

\section{2. $\mathrm{SrFe}_{1-x} \mathrm{~B}_{x} \mathrm{O}_{3-\delta}$}

\subsubsection{X-ray Diffraction Data}

The possible incorporation of borate into $\mathrm{SrFeO}_{3-\delta}$ was then examined, with samples of $\mathrm{SrFe}_{1-\mathrm{x}} \mathrm{B}_{\mathrm{x}} \mathrm{O}_{3-\delta}$ prepared for $0 \leq \mathrm{x} \leq 0.15$. The results showed that a higher borate content was achievable compared to the sulfate-doped samples, with single phase borate-doped samples for $\mathrm{x} \leq 0.1$ 
(Figure 10). In terms of the effect of borate incorporation on the structure, similar results were observed as for the $\mathrm{SrFe}_{1-x} \mathrm{~S}_{\mathrm{x}} \mathrm{O}_{3-\delta}$ samples. In particular, borate doping resulted in a similar cubic cell as for the sulfate-doped samples.

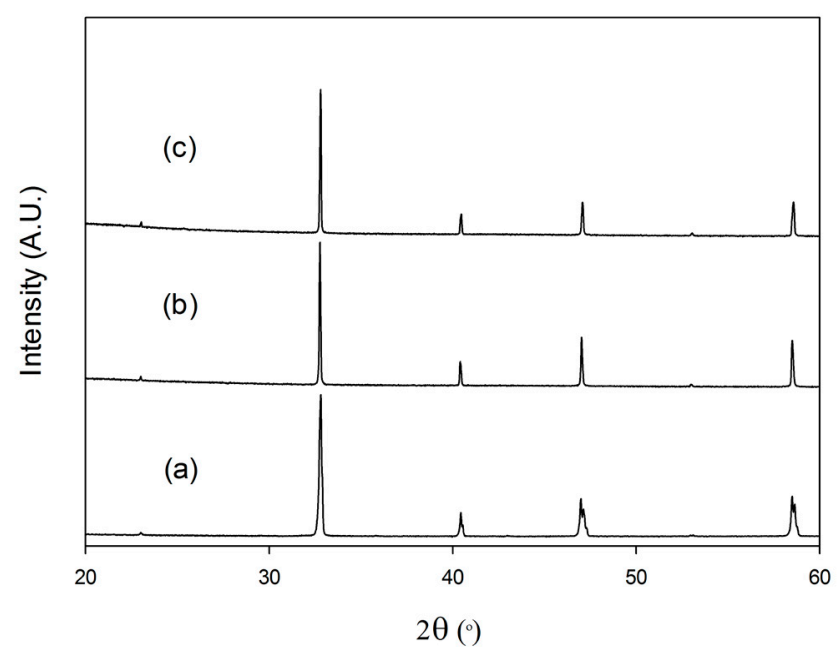

Figure 10. X-ray diffraction patterns for (a) $\mathrm{SrFeO}_{3-\delta}$, (b) $\mathrm{SrFe}_{0.95} \mathrm{~B}_{0.05} \mathrm{O}_{3-\delta}$, (c) $\mathrm{SrFe}_{0.9} \mathrm{~B}_{0.1} \mathrm{O}_{3-\delta}$.

Cell parameters and site occupancies were determined using the Rietveld method (an example fit is shown in Figure 11).

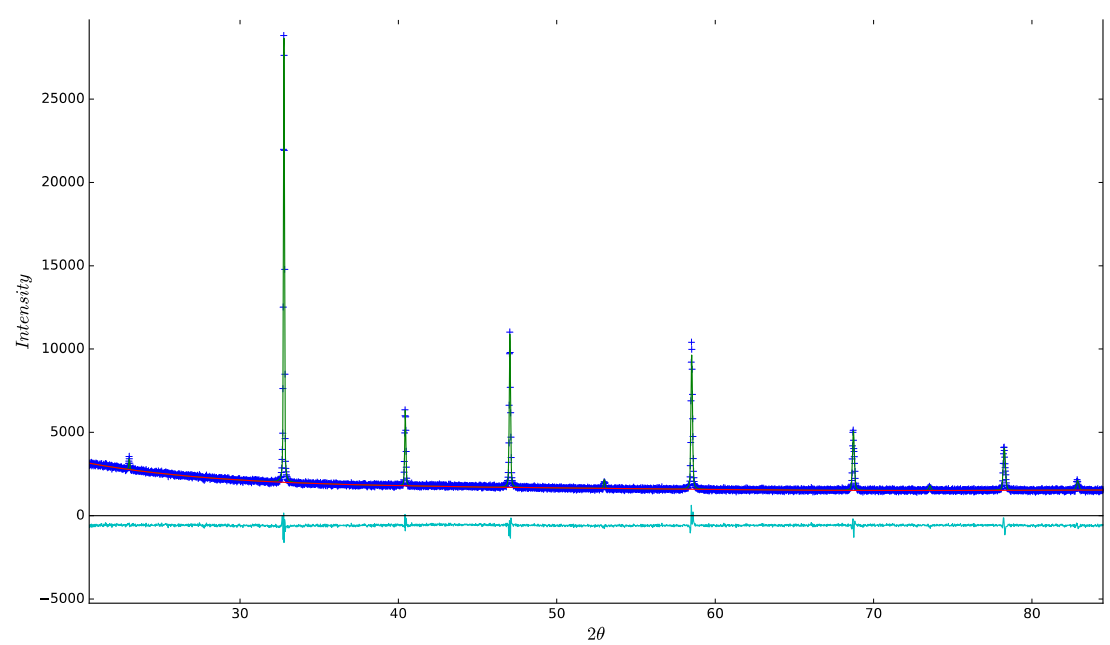

Figure 11. Observed, calculated and difference X-ray diffraction profile for $\mathrm{SrFe}_{0.95} \mathrm{~B}_{0.05} \mathrm{O}_{3-\delta}$.

The refinements gave Fe/B occupancies in good agreement with those expected (Table 4). Furthermore, in this case, a decrease in the unit cell was observed on borate doping in agreement with the smaller size of $\mathrm{B}^{3+}$ compared to $\mathrm{Fe}^{3+/ 4+}$, and the fact that unlike the situation for sulfate doping there is no additional oxygen associated with the dopant (i.e., we are effectively replacing $\mathrm{Fe}(\mathrm{III}) \mathrm{O}_{1.5}$ with $\mathrm{BO}_{1.5}$ ). 
Table 4. Lattice parameters and Fe/B site occupancies obtained from Rietveld analysis using X-ray diffraction data for $\mathrm{SrFe}_{1-\mathrm{x}} \mathrm{B}_{\mathrm{x}} \mathrm{O}_{3-\delta}$. The structure of $\mathrm{SrFeO}_{3-\delta}$ was refined using a tetragonal space group $(\mathrm{P} 4 / \mathrm{mmm})$. The structures of the doped samples were refined using a cubic space group (Pm $\overline{3} \mathrm{~m})$.

\begin{tabular}{cccc}
\hline \multicolumn{4}{c}{$\mathrm{SrFe}_{\mathbf{1}-\mathbf{x}} \mathbf{B}_{\mathbf{x}} \mathbf{O}_{3-\delta}$} \\
\hline $\mathrm{B}(\mathrm{x})$ & 0 & 0.05 & 0.1 \\
$\mathrm{a}(\AA)$ & $3.8648(1)$ & $3.8593(1)$ & $3.8561(1)$ \\
$\mathrm{c}(\AA)$ & $3.8487(1)$ & - & - \\
$\mathrm{V}\left(\AA^{3}\right)$ & $57.486(4)$ & $57.483(2)$ & $57.336(4)$ \\
$\mathrm{R}_{\mathrm{wp}}(\%)$ & 1.84 & 3.23 & 3.67 \\
$\mathrm{R}_{\text {exp }}(\%)$ & 0.92 & 2.30 & 2.52 \\
$\mathrm{Fe}$ occupancy & 1 & $0.92(1)$ & $0.89(1)$ \\
$\mathrm{B}$ occupancy & - & $0.08(1)$ & $0.11(1)$ \\
$\mathrm{Fe} / \mathrm{B}$ Uiso & $0.003(1)$ & $0.015(1)$ & $0.022(1)$ \\
\hline
\end{tabular}

\subsubsection{Stability under $\mathrm{N}_{2}$}

Heat treatment of the $\mathrm{SrFe}_{1-x} \mathrm{~B}_{x} \mathrm{O}_{3-\delta}$ samples at $950{ }^{\circ} \mathrm{C}$ under $\mathrm{N}_{2}$ showed similar results to those observed on sulfate doping, with the borate-containing samples remaining cubic after this heat treatment in nitrogen (Figure 12). In line with the reduction of the Fe oxidation state to $\mathrm{Fe}^{3+}$, there was a shift in the peak positions to lower angles, indicating a larger unit cell.

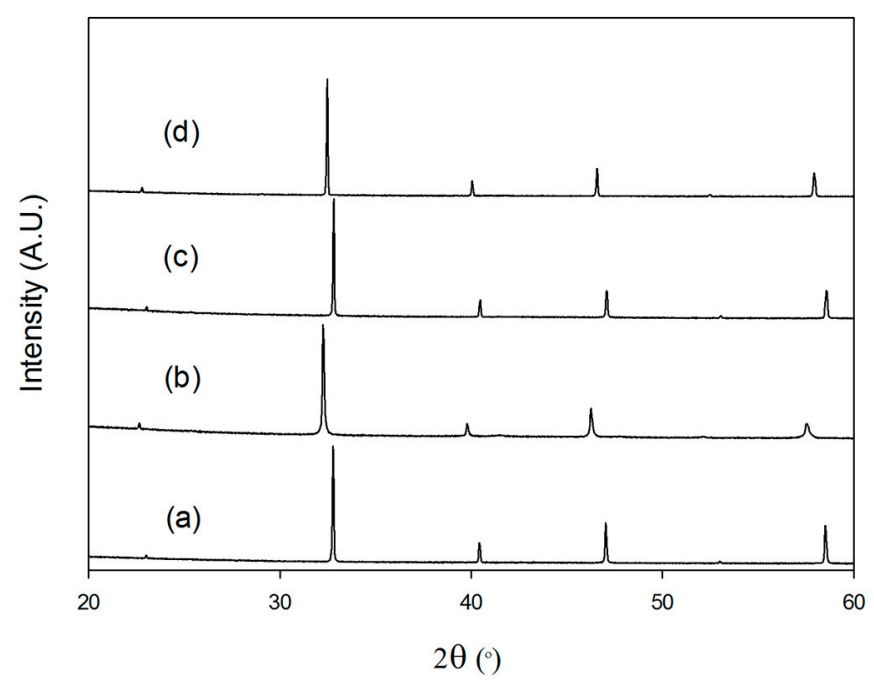

Figure 12. X-ray diffraction patterns for (a) $\mathrm{SrFe}_{0.95} \mathrm{~B}_{0.05} \mathrm{O}_{3-\delta}$, (b) $\mathrm{SrFe}_{0.95} \mathrm{~B}_{0.05} \mathrm{O}_{3-\delta}$ after heating under $\mathrm{N}_{2}$, (c) $\mathrm{SrFe}_{0.9} \mathrm{~B}_{0.1} \mathrm{O}_{3-\delta}$, (d) $\mathrm{SrFe}_{0.9} \mathrm{~B}_{0.1} \mathrm{O}_{3-\delta}$ after heating under $\mathrm{N}_{2}$.

\subsubsection{Thermogravimetric Analysis}

These samples were then analysed by TGA (heat treatment under $\mathrm{N}_{2}$ ). In contrast to the air synthesised $\mathrm{SrFe}_{1-x} \mathrm{~S}_{\mathrm{x}} \mathrm{O}_{3-\delta}$ samples, there was no mass loss due to $\mathrm{CO}_{2}$ observed in these $\mathrm{SrFe}_{1-x} \mathrm{~B}_{\mathrm{x}} \mathrm{O}_{3-\delta}$ systems, thus indicating no carbonate present.

\subsubsection{Conductivity Data}

For the $\mathrm{SrFe}_{1-\mathrm{x}} \mathrm{B}_{\mathrm{x}} \mathrm{O}_{3-\delta}$ samples $(\mathrm{x}=0.05,0.1)$, the conductivity data showed significantly lower conductivities at lower temperatures compared with the undoped system (Figure 13). However, above $600{ }^{\circ} \mathrm{C}$, the conductivities were comparable with the $\mathrm{x}=0.1$ sample, in particular showing a small improvement in the conductivity compared with undoped $\mathrm{SrFeO}_{3-\delta}$. Notably, these temperatures are in the range where operation as a cathode in a solid oxide fuel cell would be. 


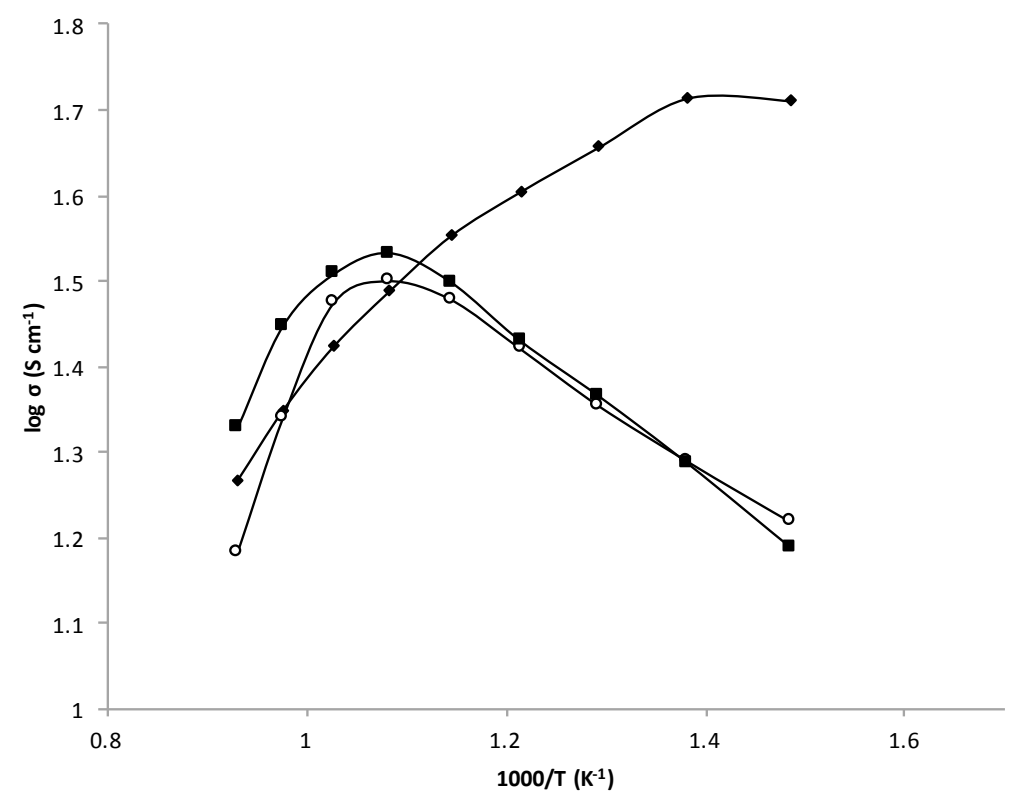

Figure 13. Plot of $\log \sigma$ vs. $1000 / \mathrm{T}$ for $\mathrm{SrFeO}_{3-\delta}(\bullet), \mathrm{SrFe}_{0.95} \mathrm{~B}_{0.05} \mathrm{O}_{3-\delta}(\bigcirc), \mathrm{SrFe}_{0.9} \mathrm{~B}_{0.1} \mathrm{O}_{3-\delta}(\mathbf{\square})$ in air.

Conductivity values (at $700{ }^{\circ} \mathrm{C}$ ) for the borate- and sulfate-doped samples are shown in Table 5, and compared to the equivalent data for silicate-doped $\mathrm{SrFeO}_{3-\delta}$ (from reference [23]). The data show similar values for all samples at this typical solid oxide fuel cell operating temperature.

Table 5. Conductivity data in air at $700{ }^{\circ} \mathrm{C}$ for $\mathrm{SrFe}_{1-x} \mathrm{M}_{\mathrm{x}} \mathrm{O}_{3-\delta}$ where $\mathrm{M}=\mathrm{Si}$ [23], $\mathrm{S}$ and $\mathrm{B}$.

\begin{tabular}{lccccccccccc}
\hline & \multicolumn{4}{c}{ Si (x) } & \multicolumn{4}{c}{ S (x) } & \multicolumn{3}{c}{ B (x) } \\
\cline { 2 - 12 } & $\mathbf{0}$ & $\mathbf{0 . 0 5}$ & $\mathbf{0 . 1}$ & $\mathbf{0 . 1 5}$ & $\mathbf{0}$ & $\mathbf{0 . 0 2 5}$ & $\mathbf{0 . 0 5}$ & $\mathbf{0 . 0 7 5}$ & $\mathbf{0 . 0 5}$ & $\mathbf{0 . 1}$ \\
\hline Conductivity $700^{\circ} \mathrm{C}\left(\mathrm{S} \mathrm{cm}^{-1}\right)$ & 26 & 21 & 35 & 18 & 26 & 25 & 30 & 25 & 30 & 32 \\
\hline
\end{tabular}

\section{Experimental}

High-purity $\mathrm{SrCO}_{3}, \mathrm{Fe}_{2} \mathrm{O}_{3},\left(\mathrm{NH}_{4}\right)_{2} \mathrm{SO}_{4}$, and $\mathrm{H}_{3} \mathrm{BO}_{3}$ were used to prepare $\mathrm{SrFe}_{1-\mathrm{x}} \mathrm{S} / \mathrm{B}_{\mathrm{x}} \mathrm{O}_{3-\delta}$ samples. Stoichiometric mixtures of the powders were intimately ground and initially heated to $900{ }^{\circ} \mathrm{C}\left(4{ }^{\circ} \mathrm{C} / \mathrm{min}\right)$ for $12 \mathrm{~h}$. Samples were then ballmilled $(350 \mathrm{rpm}$ for $1 \mathrm{~h}$, Fritsch Pulverisette 7 planetary Mill) and reheated to 1000,1050 and $1100{ }^{\circ} \mathrm{C}$ for $12 \mathrm{~h}$ with ballmilling of samples between heat treatments. For the $\mathrm{SrFe}_{1-x} \mathrm{~B}_{\mathrm{x}} \mathrm{O}_{3-\delta}(\mathrm{x}=0.05,0.1)$ samples, a higher temperature $\left(1200{ }^{\circ} \mathrm{C}\right)$ heat treatment was required to achieve single phase samples. In order to ensure maximum oxygen content, all samples underwent a final heat treatment at $350^{\circ} \mathrm{C}$ for $12 \mathrm{~h}$ in air.

Additionally, portions of the $\mathrm{SrFe}_{1-x} \mathrm{~S}_{\mathrm{x}} \mathrm{O}_{3-\delta}(\mathrm{x}=0,0.025,0.05,0.075)$ samples were heated to $900{ }^{\circ} \mathrm{C}$ under oxygen for $12 \mathrm{~h}$ with slow cooling at $50^{\circ} \mathrm{C} / \mathrm{h}$ to $350^{\circ} \mathrm{C}$, with the samples then maintained at this temperature for $12 \mathrm{~h}$ followed by cooling at $50{ }^{\circ} \mathrm{C} / \mathrm{h}$ to room temperature. To test the stability under low $\mathrm{p}\left(\mathrm{O}_{2}\right)$ conditions, both sulfate and borate-doped samples were heated under $\mathrm{N}_{2}$ to $950{ }^{\circ} \mathrm{C}$ for $12 \mathrm{~h}$.

Powder X-ray diffraction data were used in order to determine lattice parameters and phase purity. For $\mathrm{SrFe}_{1-\mathrm{x}} \mathrm{S}_{\mathrm{x}} \mathrm{O}_{3-\delta}$ samples heated in air, X-ray diffraction data were collected on a Panalytical Empyrean diffractometer equipped with a Pixcel 2D detector ( $\mathrm{Cu} \mathrm{K} \alpha$ radiation). For the remaining $\mathrm{SrFe}_{1-x} \mathrm{~S}_{\mathrm{x}} \mathrm{O}_{3-\delta}$ and $\mathrm{SrFe}_{1-\mathrm{x}} \mathrm{B}_{\mathrm{x}} \mathrm{O}_{3-\delta}$ samples, a Bruker D8 diffractometer with $\mathrm{Cu} \mathrm{K} \alpha_{1}$ radiation was used. 
Samples were also analysed using thermogravimetric analysis (Netzch STA 449 F1 Jupiter Thermal Analyser with mass spectrometry attachment). Samples were heated to $950{ }^{\circ} \mathrm{C}$ in $\mathrm{N}_{2}\left(10^{\circ} \mathrm{C} / \mathrm{min}\right)$ and held for 30 min to reduce the iron oxidation state to $\mathrm{Fe}^{3+}$.

Pellets for conductivity measurements were prepared as follows: powders of $\mathrm{SrFe}_{1-x} \mathrm{~S}_{x} \mathrm{O}_{3-\delta}$ and $\mathrm{SrFe}_{1-x} \mathrm{~B}_{\mathrm{x}} \mathrm{O}_{3-\delta}$ heated in air were initially ball milled (350 rpm for $1 \mathrm{~h}$ ), before pressing into compacts and sintering at $1100{ }^{\circ} \mathrm{C}\left(\mathrm{SrFe}_{1-x} \mathrm{~S}_{\mathrm{x}} \mathrm{O}_{3-\delta}\right)$ and $1200{ }^{\circ} \mathrm{C}\left(\mathrm{SrFe}_{1-x} \mathrm{~B}_{x} \mathrm{O}_{3-\delta}\right)$ for $12 \mathrm{~h}$ in air. Four Pt electrodes were attached with Pt paste and the samples were heated at $900{ }^{\circ} \mathrm{C}$ for $1 \mathrm{~h}$ in air. Samples were then furnace cooled to $350^{\circ} \mathrm{C}$ and held at this temperature for $12 \mathrm{~h}$ to ensure full oxygenation. Conductivities were measured using the four probe dc method.

\section{Conclusions}

The results presented in this paper demonstrate the first reports of successful incorporation of sulfate and borate into $\mathrm{SrFeO}_{3-\delta}$. This doping strategy results in a change from a tetragonal to a cubic cell, which is maintained even after heating under $\mathrm{N}_{2}$, where undoped $\mathrm{SrFeO}_{3-\delta}$ transforms to the oxygen vacancy ordered brownmillerite structure. Conductivity data in air show that the borate/sulfate-doped samples have comparable conductivities (Table 5) to undoped $\mathrm{SrFeO}_{3-\delta}$ at solid oxide fuel cell operating temperatures. Given these initial promising results, further studies are warranted to investigate the performance of these doped systems as solid oxide fuel cell cathodes.

Acknowledgments: We would like to thank EPSRC for funding (studentship for Abbey Jarvis). The raw datasets associated with the results shown in this paper are available from the University of Birmingham archive: http:/ /epapers.bham.ac.uk/3011/.

Author Contributions: P.R.S. conceived and designed the experiments; A.J. performed the experiments; A.J. and P.R.S. analysed the data; A.J. and P.R.S. wrote the paper.

Conflicts of Interest: The authors declare no conflict of interest.

\section{References}

1. Orera, A.; Slater, P.R. New Chemical Systems for Solid Oxide Fuel Cells. Chem. Mater. 2010, 22, 675-690. [CrossRef]

2. Jacobson, A.J. Materials for Solid Oxide Fuel Cells. Chem. Mater. 2010, 22, 660-674. [CrossRef]

3. Ishihara, T.; Matsuda, H.; Takita, Y. Doped $\mathrm{LaGaO}_{3}$ Perovskite Type Oxide as a New Oxide Ionic Conductor. J. Am. Chem. Soc. 1994, 116, 3801-3803. [CrossRef]

4. Hancock, C.A.; Porras-Vazquez, J.M.; Keenan, P.J.; Slater, P.R. Oxyanions in Perovskites: From Superconductors to Solid Oxide Fuel Cells. Dalton Trans. 2015, 44, 10559-10569. [CrossRef] [PubMed]

5. Francesconi, M.G.; Greaves, C. Anion Substitutions and Insertions in Copper Oxide Superconductors. Supercond. Sci. Technol. 1997, 10, A29-A37. [CrossRef]

6. Slater, P.R.; Greaves, C.; Slaski, M.; Muirhead, C.M. Copper Oxide Superconductors Containing Sulphate and Phosphate Groups. Phys. C Supercond. Appl. 1993, 208, 193-196. [CrossRef]

7. Letouzé, F.; Martin, C.; Maignan, A.; Michel, C.; Hervieu, M.; Raveau, B. Stabilization of New Superconducting Thallium Cuprates and Oxycarbonates by Molybdenum. Phys. C Supercond. 1995, 254, 33-43. [CrossRef]

8. Kinoshita, K.; Yamada, T. A New Copper Oxide Superconductor Containing Carbon. Nature 1992, 357, 313-315. [CrossRef]

9. Huvé, M.; Michel, C.; Maignan, A.; Hervieu, M.; Martin, C.; Raveau, B. A 70 K Superconductor. The Oxycarbonate $\mathrm{Tl}_{0.5} \mathrm{~Pb}_{0.5} \mathrm{Sr}_{4} \mathrm{Cu}_{2}\left(\mathrm{CO}_{3}\right) \mathrm{O}_{7}$. Phys. C Supercond. 1993, 205, 219-224. [CrossRef]

10. Goutenoire, F.; Hervieu, M.; Maignan, A.; Michel, C.; Martin, C.; Raveau, B. A 62 K Superconductor with an Original Structure: $\mathrm{Sr}_{4-x} \mathrm{Ba}_{x} \mathrm{TlCu}_{2} \mathrm{CO}_{3} \mathrm{O}_{7}$. Phys. C Supercond. 1993, 210, 359-366. [CrossRef]

11. Von Schnering, H.G.; Walz, L.; Schwarz, M.; Becker, W.; Hartweg, M.; Popp, T.; Hettich, B.; Müller, P.; Kämpf, G. The Crystal Structures of the Superconducting Oxides $\mathrm{Bi}_{2}\left(\mathrm{Sr}_{1-\mathrm{x}} \mathrm{Cax}\right)_{2} \mathrm{CuO}_{8-\delta}$ and $\mathrm{Bi}_{2}\left(\mathrm{Sr}_{1-\mathrm{y}} \mathrm{Ca}_{\mathrm{y}}\right)_{3} \mathrm{Cu}_{2} \mathrm{O}_{10-\delta}$ with $0 \leq \mathrm{x} \leq 0.3$ and $0.16 \leq \mathrm{y} \leq 0.33$. Angew. Chem. Int. Ed. Engl. 1988, 27, 574-576. [CrossRef] 
12. Maignan, A.; Pelloquin, D.; Malo, S.; Michel, C.; Hervieu, M.; Raveau, B. Stabilisation of Three New Oxycarbonates by V and Cr Substitutions The Superconductors $(\mathrm{Tl}, \mathrm{M})_{1} \mathrm{Sr}_{4} \mathrm{Cu}_{2}\left(\mathrm{CO}_{3}\right) \mathrm{O}_{7}(\mathrm{M} \mathrm{Cr}, \mathrm{V})$ and $(\mathrm{Hg}, \mathrm{V})$ ${ }_{1} \mathrm{Sr}_{4} \mathrm{Cu}_{2}\left(\mathrm{CO}_{3}\right) \mathrm{O}_{6+z}$. Phys. C Supercond. 1995, 249, 220-233. [CrossRef]

13. Shin, J.F.; Orera, A.; Apperley, D.C.; Slater, P.R. Oxyanion Doping Strategies to Enhance the Ionic Conductivity in $\mathrm{Ba}_{2} \mathrm{In}_{2} \mathrm{O}_{5}$. J. Mater. Chem. 2011, 21, 874-879. [CrossRef]

14. Pérez-Coll, D.; Pérez-Flores, J.C.; Nasani, N.; Slater, P.R.; Fagg, D.P. Exploring the Mixed Transport Properties of sulfur(VI)-Doped $\mathrm{Ba}_{2} \mathrm{In}_{2} \mathrm{O}_{5}$ for Intermediate-Temperature Electrochemical Applications. J. Mater. Chem. A 2016, 4, 11069-11076. [CrossRef]

15. Shin, J.F.; Hussey, L.; Orera, A.; Slater, P.R. Enhancement of the Conductivity of $\mathrm{Ba}_{2} \mathrm{In}_{2} \mathrm{O}_{5}$ through Phosphate Doping. Chem. Commun. 2010, 46, 4613-4615. [CrossRef] [PubMed]

16. Shin, J.F.; Apperley, D.C.; Slater, P.R. Silicon Doping in $\mathrm{Ba}_{2} \mathrm{In}_{2} \mathrm{O}_{5}$ : Example of a Beneficial Effect of Silicon Incorporation on Oxide Ion/proton Conductivity. Chem. Mater. 2010, 22, 5945-5948. [CrossRef]

17. Hancock, C.A.; Slade, R.C. T.; Varcoe, J.R.; Slater, P.R. Synthesis, Structure and Conductivity of Sulfate and Phosphate Doped $\mathrm{SrCoO}_{3}$. J. Solid State Chem. 2011, 184, 2972-2977. [CrossRef]

18. Hancock, C.A.; Slater, P.R. Synthesis of Silicon Doped $\mathrm{SrMO}_{3}(\mathrm{M}=\mathrm{Mn}, \mathrm{Co})$ : Stabilization of the Cubic Perovskite and Enhancement in Conductivity. Dalton Trans. 2011, 40, 5599-5603. [CrossRef] [PubMed]

19. Liu, Y.; Zhu, X.; Yang, W. Stability of Sulfate Doped $\mathrm{SrCoO}_{3-\delta}$ MIEC Membrane. J. Memb. Sci. 2016, 501, 53-59. [CrossRef]

20. Zhu, Y.; Zhou, W.; Sunarso, J.; Zhong, Y.; Shao, Z. Phosphorus-Doped Perovskite Oxide as Highly Efficient Water Oxidation Electrocatalyst in Alkaline Solution. Adv. Funct. Mater. 2016, 26, 5862-5872. [CrossRef]

21. Li, M.; Zhou, W.; Xu, X.; Zhu, Z. $\mathrm{SrCo}_{0.85} \mathrm{Fe}_{0.1} \mathrm{P}_{0.05} \mathrm{O}_{3-\delta}$ Perovskite as a Cathode for Intermediate-Temperature Solid Oxide Fuel Cells. J. Mater. Chem. A 2013, 1, 13632-13639. [CrossRef]

22. Porras-Vazquez, J.M.; Kemp, T.F.; Hanna, J.V.; Slater, P.R. Synthesis and Characterisation of Oxyanion-Doped Manganites for Potential Application as SOFC Cathodes. J. Mater. Chem. 2012, 22, 8287-8293. [CrossRef]

23. Porras-Vazquez, J.M.; Pike, T.; Hancock, C.A.; Marco, J.F.; Berry, F.J.; Slater, P.R. Investigation into the Effect of Si Doping on the Performance of $\mathrm{SrFeO}_{3-\delta}$ SOFC Electrode Materials. J. Mater. Chem. A 2013, 1, 11834-11841. [CrossRef]

24. Starkov, I.; Bychkov, S.; Matvienko, A.; Nemudry, A. Oxygen Release Technique as a Method for the Determination Of " $\delta$-pO2-T" diagrams for MIEC Oxides. Phys. Chem. Chem. Phys. 2014, 16, 5527-5535. [CrossRef] [PubMed] 